\title{
Digital Marketing Workshop for SMEs in Kiaracondong During COVID-19 Pandemic
}

\author{
Siti Rosimah ${ }^{1}$ \\ ${ }^{1}$ Department of Industrial Engineering, Universitas Langlangbuana, Bandung, Indonesia \\ RosimahSiti@gmail.com \\ R. Indriyati Kamil ${ }^{2 *}$, Dinna Charisma ${ }^{3}$ \\ ${ }^{2}$ Department of Communication, Universitas Langlangbuana, Bandung, Indonesia \\ ${ }^{3}$ Manajement, Faculty of Economics and Business, Universitas Langlangbuana, Bandung, Indonesia \\ rindriya73@gmail.com,dinnacharisma@gmail.com
}

(Received October 28, 2021, accepted February 07, 2022)

\begin{abstract}
In the face of the COVID-19 coronavirus pandemic, the role of small and medium enterprises (SMEs) needs to be strengthened. Especially now that small and medium enterprises are no longer seen as an alternative, but as the backbone or foundation of the country's economy. There are three things that must be considered and improved in an effort to strengthen the existence of SMEs, namely finance, improving Human Resources (HR) and innovating marketing models through digital technology. MSMEs in Kiaracondong District which are engaged in culinary and handicrafts are small businesses owned and developed by individuals in the guidance, direction and supervision of the Head of the Economic and Development Section at both the sub-district and village levels. In the time of COVID-19 pandemic, the majority of MSMEs in the Kiaracondong sub-district tend to experience a decrease in sales turnover, this is because the marketing of their products is still done conventionally and only around the neighborhood where they live. Therefore, the Langlangbuana University community service team provides assistance to SMEs to develop their entrepreneurial spirit, through discussion methods and FGDs for product innovation assistance, sales promotion strategies, online marketing strategies and digital literacy. The results of the mentoring activity showed that the SME participants in the Kiaracondong sub-district actively participated in mentoring activities and could understand the strategy for developing product variations and understanding digital literacy in marketing their products through social media such as Whatsapp groups and business WhatsApp, Facebook, and Instagram.
\end{abstract}

Keywords: COVID-19; digital literacy; entrepreneurship; Kiaracondong SMEs; small and medium enterprises 


\section{Introduction}

Since the coronavirus outbreak has spread in the world, many sectors have been affected by the pandemic crisis, including the small and medium economic sector. Several industries were forced to close voluntarily to stop the spread of the COVID-19 virus in the factory environment (Baldwin, 2020). The tourism, education, entertainment, and recreation sectors were also affected. Another effect affected by COVID-19 is small and medium enterprises (Mthethwa and Nwone, 2021). The upheaval caused by the spread of COVID-19 is negatively impacting small businesses. The COVID-19 pandemic has had a negative impact on the MSME sector, causing SMEs to have to reduce the production of goods/services, reduce the number/hours of employees and the number of sales/marketing channels.

A review of data on the impact of COVID-19 on micro, small and medium-sized enterprises indicates that the economic impact of this pandemic will be even worse for small and mediumsized enterprises (Liguori \& Pittz, 2020). Since the beginning of 2020, around $90 \%$ of small and medium business activities in Indonesia have experienced shocks. There are around 37,000 small and medium business actors who reported to the Ministry of Cooperatives. From the report data, $56 \%$ reported that there was a decrease in sales, $22 \%$ admitted to having capital difficulties, $15 \%$ reported that there was an obstruction in distribution, and $4 \%$ reported difficulties in raw materials (Ministry of Cooperatives, 2020). Another impact of this pandemic is a wave of massive layoffs. The Ministry of Manpower noted that until December 2020 the number of unemployed due to the pandemic reached 2.67 million people (cnbcindonesia.com, 11 December 2020).

The COVID-19 pandemic caused some Indonesians to experience layoffs. Those affected by the layoffs were trying to survive by opening a micro-scale home-based business. Most of these home-based businesses produces various foods to be practical in processing and selling. The Ministry of Cooperatives and SMEs stated that small and medium enterprises in the food sector that produce herbal products, fruits and vegetables provide practical food that is easy to process and can be stored for a long time, such as frozen food, and ready-to-use spices, are those which recorded the highest increase in terms of turnover and quantity of small and medium business craftsmen. 
Small and Medium Enterprises (SMEs) are a top priority for many governments and play a significant role in absorbing labor so that they are an important part of the country's economy (Thaha et al, 2021). Small and medium enterprises are believed to be the main pillars of economic development, so they should be given encouragement, opportunities, and support as a form of siding with the people's economy. Small and medium enterprises can be seen as a savior valve in the process of national economic recovery and have proven to survive the crisis, this is because they do not have foreign debt, do not have much debt to banks so they are considered unbankable, use more local inputs, and are export oriented. Therefore, the role of MSMEs in encouraging the rate of economic growth and employment is expected to be the first step for efforts to move the production sector in various business fields. MSMEs in Kiaracondong District which are engaged in culinary, and handicrafts are small businesses owned and developed by individuals in the guidance, direction, and supervision of the Head of the Economic and Development Section at both the sub-district and village levels. In the time of COVID-19 pandemic, the majority of MSMEs in the Kiaracondong sub-district tend to experience a decrease in sales turnover, this is because the marketing of their products is still done conventionally and only done around the neighborhood where they live. One of the MSME business sectors in Kiaracondong that was affected by the COVID-19 pandemic is culinary, which has experienced a decline in turnover, especially business actors who sell their products face-to-face to the buyers. Digital literacy was done for developing the quality of MSME governance (Dyah et all, 2016). Digital literacy can be used to measure the extent to which MSMEs are able to utilize information technology (Gunawan, 2021). The constraints faced in mastering digital marketing are largely due to the lack of understanding of marketer about internet usage and not having workers who understand information technology (Anggraini, 2019).

Another problem with MSME actors in Kiaracondong District, Bandung City is the lack of information to access funding through banking schemes, as well as the lack of counseling or training for MSMEs about media digitization, the potential of social media as a means of promotion. Therefore, the Langlangbuana University community service team seeks to help SMEs to develop their entrepreneurial spirit, through product innovation assistance, sales promotion strategies, online marketing strategies and digital literacy in a sustainable manner. The implementation of this mentoring activity was expected to provide them with provisions to face competition in the future, in addition to providing them with assistance regarding the importance of implementing digital technology in product marketing activities, 
entrepreneurship knowledge that has business ethics, handling customer complaints and how to manage finances effectively.

\section{Methods}

Solutions to problems regarding the development of an entrepreneurial spirit and digital literacy in the marketing of MSME products for mentoring participants were carried out using both onsite and online discussion methods about various problems and obstacles faced by each MSME actor in carrying out their business, marketing, and their business yields during the COVID-19 pandemic. Providing offline and online materials on entrepreneurship and digitalization of the marketing of the products they offer, technical assistance on the use of smartphones as learning media about entrepreneurship and product marketing, onsite and online technical assistance regarding registration and marketing of their products in various online marketing media.

This method was carried out in coordination with the Head of the Economic and Development Section in the Kiaracondong district to gather MSMEs that require entrepreneurship and digital literacy assistance in marketing their products. Selected MSMEs from 6 sub-districts those were accompanied by each head of the economic and development section of the 6 sub-districts coordinated with the PKM team to plan mentoring activities. This assistance was carried out from October to December 2020. The stages of implementing the method of implementing community service in the Kiaracondong sub-district include the coordination and information dissemination stages, conducting focus group discussions (FGD). The FGD was carried out by opening a dialogue between the PKM team and MSMEs and sub-district parties to gather information and identify problems, then the mentoring process was carried out through various trainings, both online and offline.

The following is a flowchart of the stages of implementing PKM Langlangbuana University to partners: 


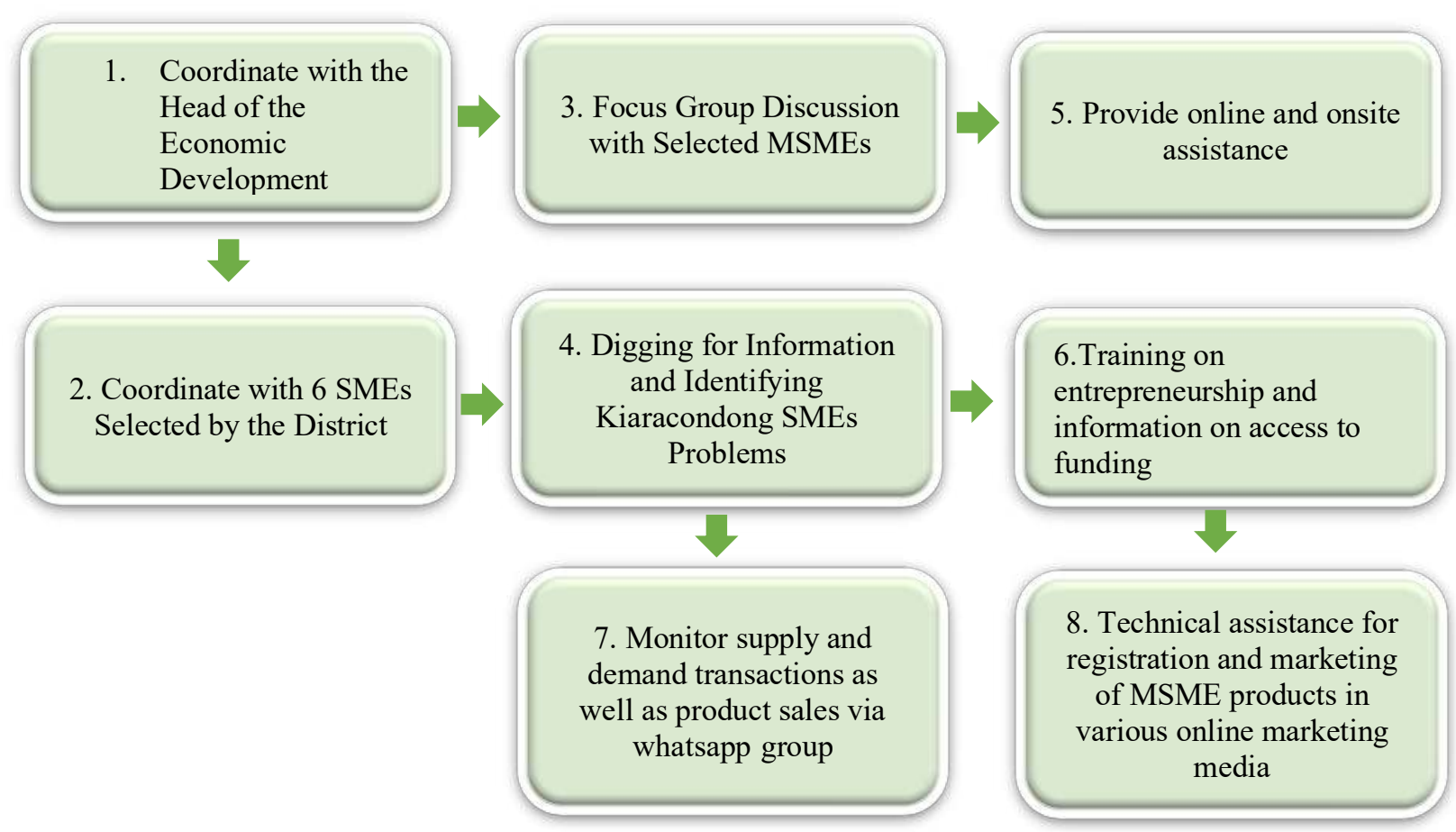

Fig. 1. Stages of implementing training to the community

\section{Results and Discussions}

The main partner in this PKM activity is the Head of the Economic and Development Section of Kiaracondong District. The participation of the Head of Ekbang in the implementation of PKM UNLA was very intense from the initiation of PKM activities, the implementation process and until the common perception of the expected final results of UNLA PKM activities. The main partner's participation included direct involvement in the planning of PKM activities in the sub-district and determining MSME participants as the target of mentoring. The subdistrict head instructed the Head of Ekbang at the Village level to coordinate and assist MSMEs during the UNLA PKM mentoring period, and there were 6 MSMEs selected to participate in entrepreneurship and digital literacy assistance, including Mpek-Mpek MSMEs, Cilok MSMEs, Pasar Snacks MSMEs, Snackbox MSMEs, Rice MSMEs box and mineral water glass ring craftsmen.

Assistance provided to partner MSMEs includes technical training on the use of smartphones to increase sales turnover by registering and marketing their products on various online marketing applications such as Go Food, Grab Food, Tokopedia, Shopee, Lazada, Bukalapak, also the use of social media such as Facebook, Instagram, Tiktok and others to increase sales turnover, facilitate technical design of promotional content and online product marketing, as 
well as the concept of entrepreneurship and MSME capital. The following is documentation of the assistance of the PKM team at Langlangbuana University Bandung in Kiaracondong subdistrict:
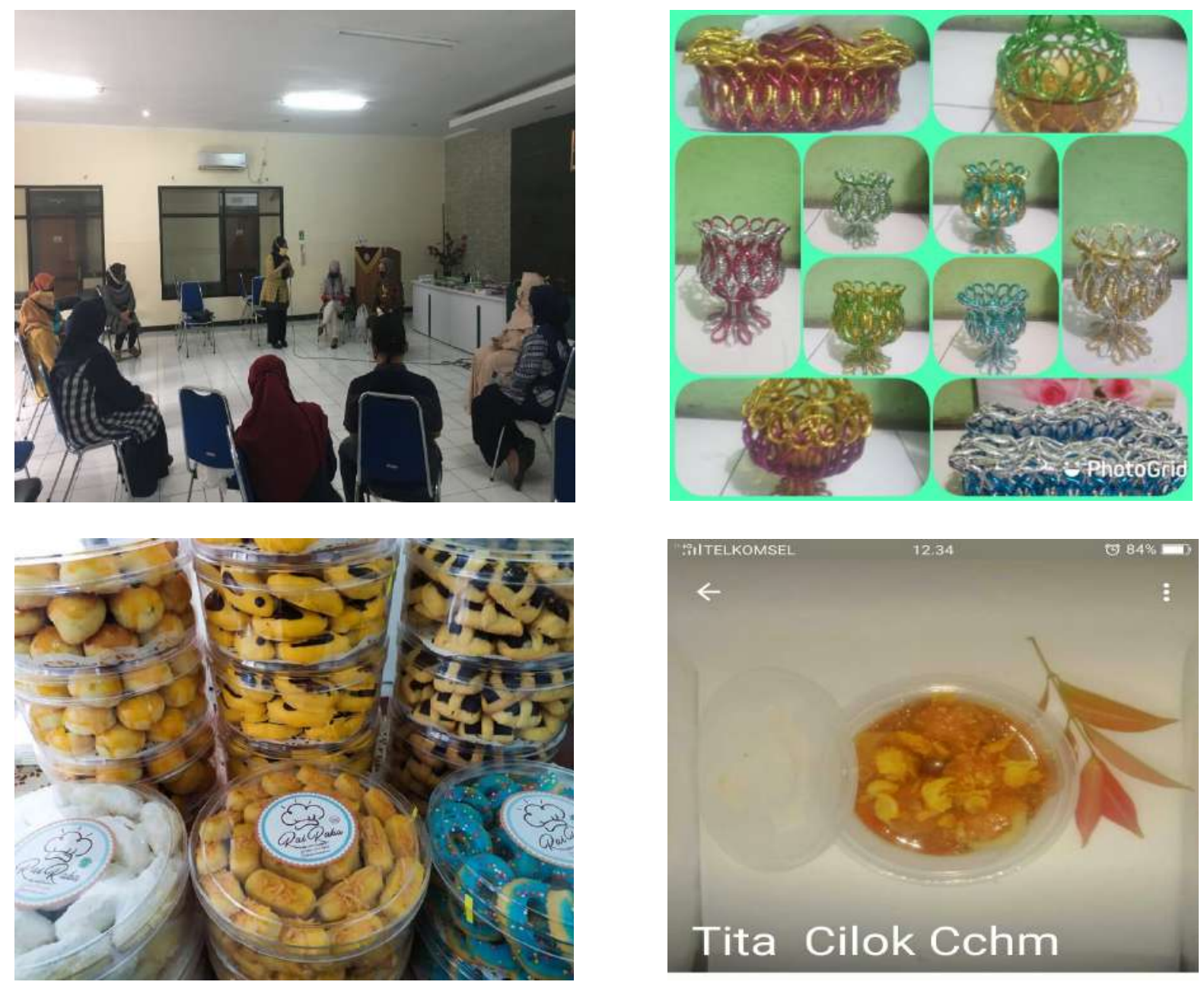

Fig. 2. Digital literacy training and Kiaracondong MSME products

The results of community service are in the form of increasing understanding and knowledge of partners about entrepreneurship and the use of smartphones for their business activities. The results of the service and progress obtained by the PKM group mentoring partners can be seen in Table 1. 
Table 1. The results of digital literacy assistance activities for MSMEs

\begin{tabular}{|c|c|c|}
\hline No & Problem & Partner's results/progress \\
\hline 1. & $\begin{array}{l}\text { The difficulties faced by Head of the Economic } \\
\text { and Development Section of Kiaracondong } \\
\text { District in fostering and assisting MSMEs in the } \\
\text { time of the COVID-19 pandemic }\end{array}$ & $\begin{array}{l}\text { PKM partners gained knowledge and hands-on practice about } \\
\text { entrepreneurship and digitalization techniques for marketing } \\
\text { their products }\end{array}$ \\
\hline 2. & $\begin{array}{l}\text { MSME actors have experienced difficulties in } \\
\text { accessing funding for business activities, } \\
\text { especially since the era of the COVID-19 } \\
\text { pandemic }\end{array}$ & $\begin{array}{l}\text { MSME partners obtained information about various financing } \\
\text { from banks for MSMEs and technical and access }\end{array}$ \\
\hline 3. & $\begin{array}{l}\text { MSME actors have difficulty in developing their } \\
\text { business related to the variety of products } \\
\text { offered to consumers }\end{array}$ & $\begin{array}{l}\text { MSME partners obtained information in scientific and technical } \\
\text { information regarding the development of product variations } \\
\text { offered, as evidenced by: } \\
\text { - cilok entrepreneurs who initially only offered their products } \\
\text { with only one peanut flavor variant are now developing } \\
\text { with the innovation of the cilok flavor variants offered } \\
\text { - mineral glass ring craftsmen goes into various forms of } \\
\text { crafts and variants of various color combinations } \\
\text { - entrepreneurs of various cakes and market snacks make and } \\
\text { offer a wide variety of cakes } \\
\text { - rice box entrepreneurs offer a variety of prices and menu } \\
\text { variations in marketing their products } \\
\text { - pempek entrepreneurs offer various price packages and } \\
\text { accompanying menus } \\
\text { snackbox entrepreneurs offer various price packages and } \\
\text { packaging }\end{array}$ \\
\hline 4. & $\begin{array}{l}\text { MSME actors have difficulty in marketing their } \\
\text { products due to the limitations of MSMEs in } \\
\text { reaching customers in addition to social } \\
\text { restrictions related to government policies in } \\
\text { preventing the spread of covid } 19 .\end{array}$ & $\begin{array}{l}\text { - From the results of interviews at the end of the onsite } \\
\text { meeting, information was obtained that most of the } \\
\text { mentoring participants had understood the use of } \\
\text { smartphones to market their products although they were } \\
\text { still reluctant to use e-commerce that already existed at this } \\
\text { time on the grounds of profit sharing (percentage) so that } \\
\text { they felt inadequate with their current conditions. but their } \\
\text { understanding and knowledge has improved and can be } \\
\text { used when they feel the need } \\
\text { Almost all MSMEs prefer to digitize their product } \\
\text { marketing through social media such as whatsapp groups } \\
\text { and business whatsapp, facebook and instagram }\end{array}$ \\
\hline
\end{tabular}

- Head of the Economic and Development Section of Kiaracondong District head held photography training using smartphones with speakers from Telkom University for all MSMEs in the Kiracondong sub-district and MSMEs participating in PKM UNLA assistance were included in the activity although not all of them wanted to participate.

5. Some MSME actors have difficulty in displaying the products offered to consumers digitally

- MSME participants can organize the products they offer digitally so that they can attract potential consumers

- UNLA PKM mentoring participants who take part in photography training share knowledge and teach it online via whatsapp and practice it during offline meetings

- MSME mentoring participants already know and understand various e-commerce applications and how to register their business, but only some MSMEs want to register their business on the gofood application while other applications still do not want to do it because of the requirements

6. MSME actors have difficulty in using various e-

- All mentoring participants prefer to use the whatsapp group commerce to market their products application and its network to market their products digitally because it is easier and safer and monitoring the products sent to customers is relatively easy and avoids consumer complaints 


\section{Conclusion}

The science and technology delivered in the digital literacy and entrepreneurship assistance from PKM Langlangbuana University are as follows:

1. Utilization of smartphones to support business activities

The digital literacy that provided to MSME actors was able to increase the insight and understanding of business actors to be more media literate by utilizing smartphones to support their business activities, especially to market their products digitally. The PKM UNLA team's assistance to MSMEs in Kiaracondong District was aimed at maximizing the effectiveness of digital product marketing by utilizing existing e-commerce applications and social media that they were accustomed to using. In the digital marketing mentoring session, the PKM team provided technical guidance on the procedures for listing in various ecommerce sites, as well as techniques for displaying and delivering their products on various digital product marketing media.

Submission of material and technical use of e-commerce applications by the PKM team is intended to attract potential buyers in various e-commerce applications. After mentoring, the selected MSMEs were finally able to understand various business applications through smartphones to market their products including Shopee, Lazada, Tokopedia, Bukalapak, Gojek and Grab. In addition to digital product marketing e-commerce applications, they can also take advantage of social media such as Facebook, Instagram and WhatsApp. The techniques and procedures were conveyed but in the end it was the MSME actors who decided to use the application or not. From the mentoring participants, they were more comfortable marketing their current products via the whatsapp application, both business whatsapp and personal whatsapp because they feel safe and also to avoid fraud because these applications are relatively well known to buyers. However, these MSME actors still try to register in several e-commerce applications.

\section{Entrepreneurial spirit}

The MSME actors in the Kiaracondong district already have a proven high entrepreneurial spirit, they still exist and survive running their business even in the pandemic time. Therefore, during the mentoring period, they always tries to develop an innovative, creative, optimistic spirit and the courage to take risks proportionally. 
Based on this, the mentoring strategy carried out by the Langlangbuana University PKM team focuses more on optimizing marketing techniques in an innovative and creative way and understanding consumer needs so that the results of the innovation can be absorbed by consumers. Thus, the risks that must be borne by MSME actors can be minimized.

\section{Access to MSME funding}

Access to funding is a supporting aspect in the mentoring process carried out by the UNLA PKM team for Kiaracondong MSMEs. Information that can be accessed by MSMEs related to funding includes the People's Business Credit (KUR) which is working capital and investment financing for individual debtors, business entities or business groups that are productive and feasible but do not have additional collateral or additional collateral is not enough. The distribution of KUR can be done directly in the sense that MSMEs can directly access KUR at the Branch Office or Sub-Branch Office of the Implementing Bank, or it can also be done indirectly by accessing KUR through Microfinance Institutions and KSP Cooperatives, or through other program linkage activities that work together. with the Implementing Bank.

The follow-up to the Langlangbuana University PKM activities is to simultaneously monitor and help disseminate information digitally via networks about the marketing of MSME products for PKM partners, provide material and understanding of fast, accurate and highquality digital customer service through WhatsApp groups that have been formed and are still in progress, supervision and evaluation of the Head of the Economic and Development Section of Kiaracondong District and sub-district team.

\section{Acknowledgements}

The implementation of community service activities to the community is successful, thanks to the cooperation of various parties, including:

1. The Rector of Langlangbuana University who has facilitated mentoring activities for SMEs in carrying out community service in Kiaracondong District

2. The Head of Kiaracondong Sub-district has allowed and facilitated PKM team to carry out mentoring activities for SMEs in each Kelurahan and Sub-district. 


\section{References}

Anggraini, O. (2019). Literasi Digital: Suatu Kemewahan bagi UMKM Perikanan di Era Industri 4.0? Seminar Dan Lokakarya Kualitatif Indonesia. Pengembangan Budaya Penelitian menuju Indonesia 4.0. https://doi.org/10.33510/slki.2019.117-126.

Ayodya, W. (2020). UMKM 4.0: Strategi UMKM Memasuki Era Digital. Jakarta: PT Elex Media Komputindo.

Baldwin, R., Mauro, B. W., (2020). Book of Economic in the Time of Covid-19. CEPR Press VoxEU.org

Dyah, A., et al. (2016). Literasi Digital pada Perempuan Pelaku Usaha Produktif di Daerah Istimewa Yogyakarta. Jurnal ASPIKOM, Volume 3 No. 1, July 2016, page 1-15.

https://investor.id. Kemenkop UKM: 90\% UMKM Terdampak Pandemi Covid. Accessed October 30, 2020.

https://www.cnbcindonesia.com. Pengangguran RI "Meledak", Tambah 2,67 Juta Orang Saat Corona. Accessed December 11, 2020

Gunawan Y. (2021). ANALISA LITERASI DIGITAL USAHA MIKRO, KECIL, MENENGAH (UMKM) MAKANAN ISLAMI DALAM KEMASAN (Studi Deskriptif tentang Tingkat Kompetensi Literasi Digital pada UMKM di Kota Jember). http://jurnal.unmuhjember.ac.id/index.php/JMBI/article/view/5072/3380. Vol 7, No 1.

Liguori E. W, Pittz T. G. (2020). Strategies for small business: Surviving and thriving in the era of COVID-19. Journal of the International Council for Small Business (2020). DOI: $10.1080 / 26437015.2020 .1779538$

Mthethwa L., Nwone S.A. (2021). A Bibliography on Socio-economic and Cultural Impacts of Covid-19 Pandemic. Library Philosophy and Practice (e-journal). https://digitalcommons.unl.edu/libphilprac/5182

Thaha A.R., Maulina E., Muftiadi R.A., Alexandri M. B. (2021). Digital Marketing and SMEs: A Systematic Mapping Study. Library Philosophy and Practice (e-journal). https://digitalcommons.unl.edu/libphilprac/5113. 